\title{
Teachers' Perception about Flipped Classroom in Era of COVID-19 Pandemic
}

\author{
${ }^{*}$ A Yadav ${ }^{1}$, M Sankhla ${ }^{1}$, K Yadav ${ }^{1}$ \\ 1Department of Physiology, SMS Medical College, Jaipur (Rajasthan) India- 302004
}

\begin{tabular}{|c|c|}
\hline Article Info & ABSTRACT \\
\hline $\begin{array}{l}\text { Article history: } \\
\text { Received July 18, } 2021 \\
\text { Revised September 4, } 2021 \\
\text { Accepted September 8, } 2021 \\
\text { Available Online September 9, } 2021\end{array}$ & $\begin{array}{l}\text { The COVID-19 affects medical education by shifting classroom } \\
\text { teaching to online mode, facing numerous challenges, particularly in } \\
\text { developing countries, such as internet connectivity, technological } \\
\text { issues, mode of assessment. Teachers' perspectives and various } \\
\text { challenges affecting the e-learning system during the COVID-19 }\end{array}$ \\
\hline $\begin{array}{l}\text { Keywords: } \\
\text { COVID-19 } \\
\text { E-learning } \\
\text { Medical Education } \\
\text { Pandemic } \\
\text { Online teaching }\end{array}$ & $\begin{array}{l}\text { pandemic require attention to ensure effective learning, so the present } \\
\text { study aimed to assess the above objective. After institutional ethical } \\
\text { committee approval, a cross-sectional observational study was } \\
\text { conducted on teachers ( } 30 \text { responded) of phase-I MBBS via a survey } \\
\text { questionnaire. The qualitative data were analyzed using chi-square, } \\
\text { with a significance level set }<0.05 \text {. The majority of teachers were } \\
\text { female }(70 \%) \text { and Generation } X(60 \%) \text {, with an } 81 \% \text { response } \\
\text { rate. Faculty (53\%) had a positive impression of online teaching but } \\
\text { preferred face-to-face instructions }(67 \%) \text {. With a non-significant } \\
\text { difference (p=0.255), the majority of the teaching staff sometimes faces } \\
\text { network and technology challenges but satisfies with online teaching } \\
\text { and assessments. Faculty prefer traditional classroom learning and } \\
\text { assessment as they miss student participation and feedback, with prior } \\
\text { e-teaching training and platform privacy but recognized online mode } \\
\text { as an alternative during COVID- } 19 \text {. The faculty had a positive attitude } \\
\text { towards online teaching but lack face-to-face interaction with students. } \\
\text { Internet access, combined with some technical difficulties, posed a } \\
\text { challenge in providing high-quality teaching. }\end{array}$ \\
\hline
\end{tabular}

\section{INTRODUCTION}

The COVID-19 pandemic forced educational institutes to close temporarily, disrupting the education system and 1.7 billion students globally (Nicola et al., 2020; UNESCO, 2020). As a result of the pandemic's emergence, the online classroom has become an essential tool for maintaining normal teaching order and preventing virus infection (World Health Organization, 2019). Shifting to e-teaching was a challenge, especially for medical education which needs practical skills as well. COVID-19 has a profound impact on medical (Mian \& Khan, 2020; Rose, 2020; Kanneganti, et al., 2020; Sandhu \& Wolf, 2020) and dental students (Iyer, et al., 2020) and radiology trainees (Alvin, et al., 2020). Our institution used the cisco WebEx online platform to deliver e-lectures to restore regular teaching from May 2020. Online learning provides several advantages over traditional classroom teaching methods, including time and location flexibility, time savings (no commute time), convenience, and student accessibility (Panchabakesan,2011). However, these online education platforms have numerous challenges, including lack of motivation, anxiety during online learning (Simamora 2020), internet connectivity (Tabatabai, 2020), and technological issues in conducting e-lectures, student assessments, communication, and a lack of in-person interaction (Esani, 2010; Christiane Amanpour, 2020.). Many teachers are technophobic 
as they are concerned about or unsure how to cope with computer hardware and software problems in the classroom (Rosen, \& Weil,1995). During an emergency, challenges to the online environment may delay the adoption of technology-enabled education (Chiasson, et al., 2015).

Adopting e-learning systems in developing countries remains a challenge in reality. Inadequate network connectivity during delivering e-lectures system usage hampers the benefits of the e-learning system. A thorough analysis of challenges and factors influencing the e-learning systems during the COVID-19 pandemic is needed. The majority of e-learning research has focussed on students, but teachers' perspectives have not been explored. thoroughly. For effective e-learning, it is necessary to assess whether online education can become an effective means especially in medical education that also requires practical skills, whether these online education platforms meet the needs and satisfaction of teachers, whether online teaching can complete the teaching tasks with high quality.

The present study aimed to assess teacher's perceptions, attitudes, suggestions, satisfaction with online teaching and assessment, and focus on various challenges-internet connectivity, and technological issues affecting e-learning system usage during the COVID-19 Pandemic.

\section{RESEARCH METHOD}

A cross-sectional observational study was conducted after taking permission from the institutional ethical committee and consent from participants to identify the satisfaction, perceptions, and experiences of faculty members for online teaching during the early lockdown period due to COVID-19 pandemic. The purpose of the present study was briefed to the teaching faculty of phase-1 MBBS who were taking online classes during the pandemic and the google form link of the 19-item questionnaire (open and close-ended) was shared with them by WhatsApp or E-mail. The participation was voluntary and the confidentiality of the participants was assured. The response to the google form was considered as acceptance of participation and the teachers not taking the online lectures or not responded to the google form were excluded from the study. The teachers from 3 specialties - Anatomy, Physiology, and Biochemistry participated in the survey. The online classes were conducted on the cisco-WebEx platform that was provided by the college with technical support.

A total 30 teachers' response was obtained in the feedback survey, after removal of 4 duplicate results and one incomplete form, teacher's data was compiled and analyzed in Excel Microsoft. The comment analysis was also performed for open-ended questions. The Chi-square test was applied to find the significance level in various groups with the help of primer version7. The $P$-value $<.05$ was considered significant.

\section{RESULTS AND DISCUSSION}

The present study exhibits the different factors influencing e-learning and also analyzed the various challenges faced by medical teachers during the transition from offline to online medical education during the COVID-19 pandemic. The present study response rate was $81 \%$ and participated faculty belong to different generations. The generations were classified as follows based on the year of their birth: Baby Boomers (1946- 1964), Generation X (1965-1980), the Millennials or Generation Y (1981-1996), and Generation Z or Post-Millennials (1997-2012) (Dimock, 2019). The majority of participants were females (70\%) as compared to males (30\%) and belonged to Generation X- 18 (60\%), followed by Generation Y- $9(30 \%)$ than Baby Boomers- 3 $(10 \%)$. No faculty belongs to Generation $Z$. The teaching faculty proportion was nearly the same for all designation (Senior Demonstrator 27\%, Assistant 27\%, Associate 20\%, and Professors 27\%). Baseline characteristics of study respondents were depicted in figure 1. 


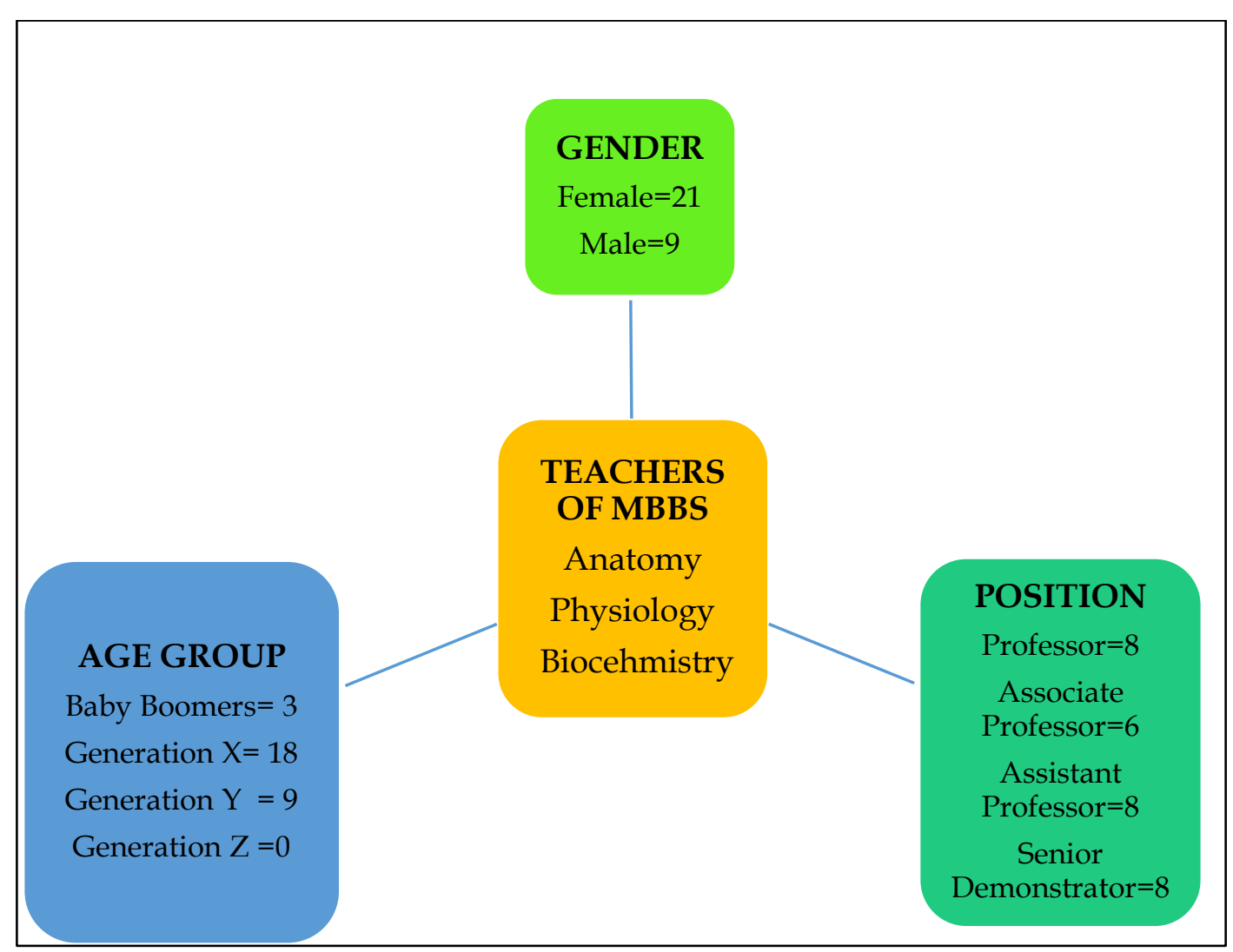

Figure 1. An overview of the profile of teachers of MBBS (Phase-I) of the medical educational institute (number of teachers $=30$ )

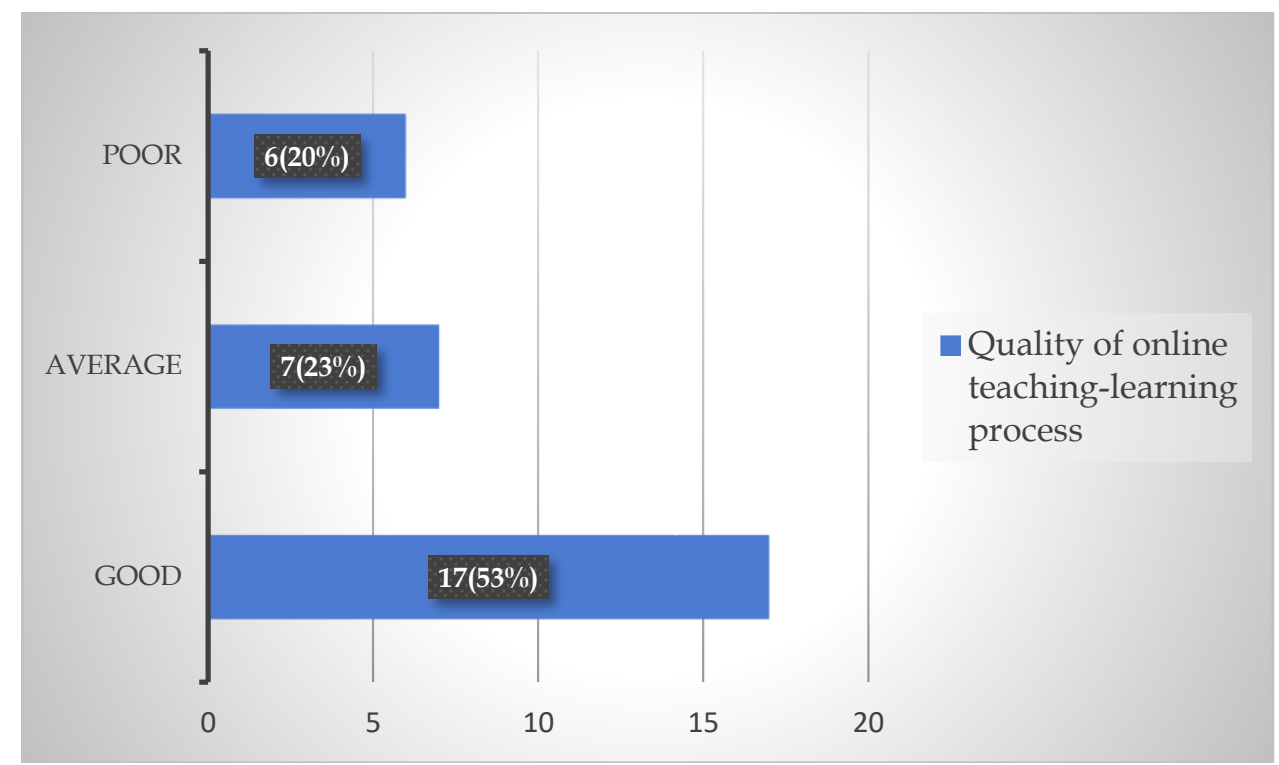

Figure 2. Overall perception of medical faculty about quality of online teaching-learning process

The perception of teaching faculty about the overall quality of online teaching was good by the majority of staff $(>1 / 2), 1 / 4$ experienced average and the remaining $1 / 4$ participants had a poor perception of the online teaching-learning process (Figure 2). 


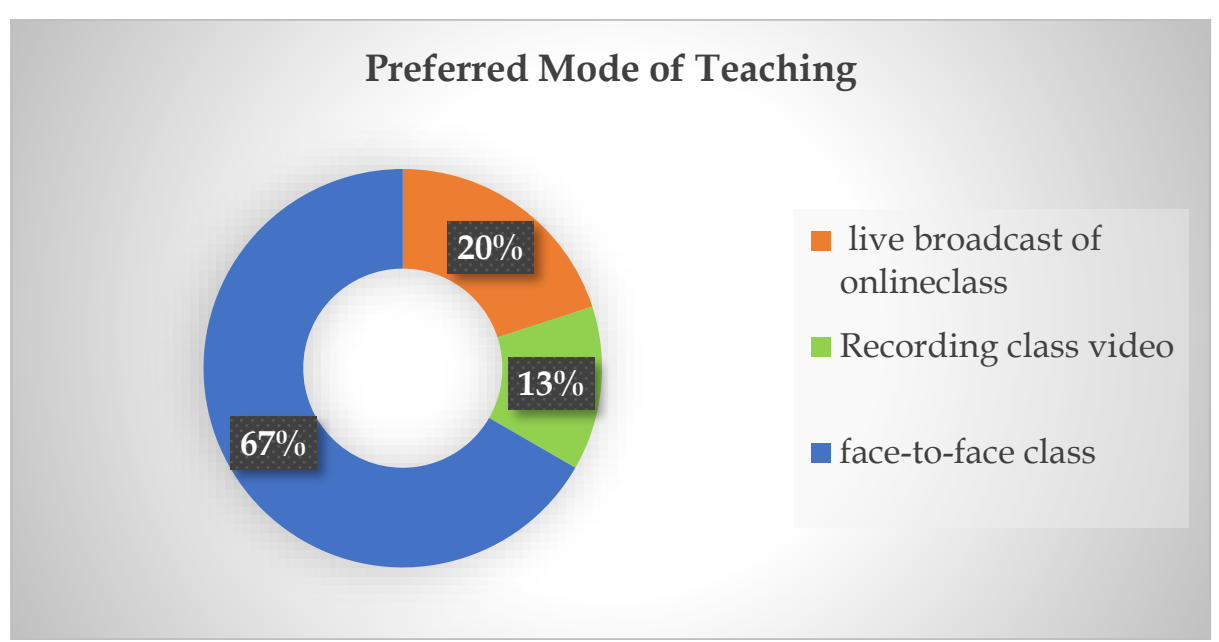

Figure 3: Perception of preferred mode of medical education by teachers (number of teachers $=$ 30)

The majority of teaching faculty $\left(2 / 3^{\text {rd }}\right)$ preferred face-to-face teaching, while the remaining $\left(1 / 3^{\text {rd }}\right)$ preferred live broadcasts followed by recorded class videos (Figure 3 ).

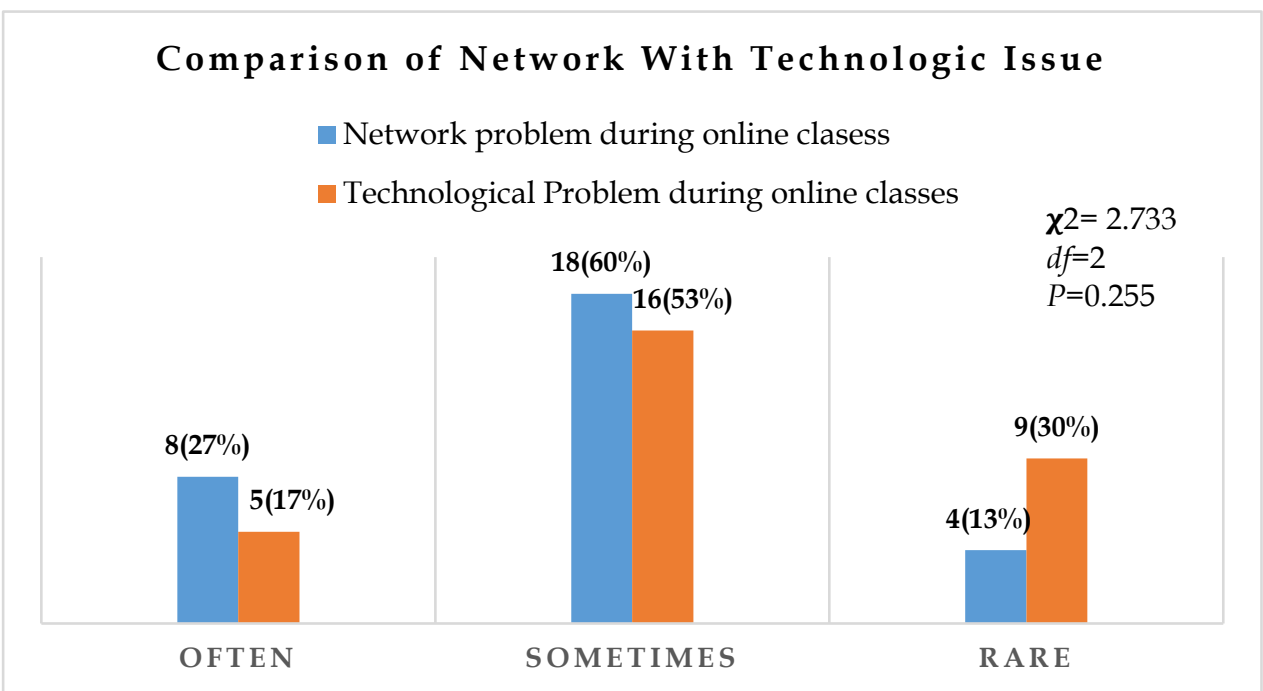

Figure 4. Comparison of network problem with technological issues during online classes

Most of the faculty ( $>1 / 2)$ sometimes faced network connectivity problems or slow speed of the internet. Only $13 \%$ of staff rarely face any network connectivity issue. Technological issues during e-lectures were also experienced sometimes by half of the staff members while $1 / 3^{\text {rd }}$ never experienced any such challenges and only $<1 / 3^{\text {rd }}$ confronted with this technological situation. The difference between technical and network connectivity obstacles was statistically nonsignificant (Figure 4). Similarly, just $1 / 3$ of the teaching faculty $(n=10)$ had confidence in the technology utilized for online education, with 13 staff members being neutral and 7 dissatisfied with the system's reliability.

Table 1. Comparison of Medical teachers' satisfaction with Online Teaching and Online Assessment.

\begin{tabular}{lccc}
\hline Satisfaction level of Teachers & $\begin{array}{c}\text { Online Teaching } \\
\text { n (\%) }\end{array}$ & $\begin{array}{c}\text { Online Assessment } \\
\text { n (\%) }\end{array}$ & $\begin{array}{c}\text { Chi-Square } \\
\text { Significance }\end{array}$ \\
\hline Satisfied & $13(43 \%)$ & $14(47 \%)$ & $\chi 2=0.104$ \\
Neutral & $8(27 \%)$ & $7(23 \%)$ & $d f=2$ \\
Unsatisfied & $9(30 \%)$ & $9(30 \%)$ & $P=0.949$ \\
\hline
\end{tabular}

$P<.05$ Significant

$\mathrm{n}=$ Number of subjects 
Nearly one-half of the teaching faculty was satisfied with online teaching (43\%) and online assessment (47\%), while a quarter of faculty was neutral about their opinion and the remaining $30 \%$ were unsatisfied with the online mode of teaching as well as assessment of MBBS students. There was no discernible difference between online instruction and online assessment. There was a non-significant difference between online teaching and assessment. The viewpoint of teaching faculty about "online mode of assessment, covered all learning domains" was varied; the majority were unsatisfied $(n=24)$, only four were satisfied, and two were neutral about their opinion on this issue.

Table 2. Attitude of Medical teachers towards Online Teaching and Assessment

\begin{tabular}{lccc}
\hline Questionnaire & $\begin{array}{c}\text { Agree } \\
\mathbf{( \% )}\end{array}$ & $\begin{array}{c}\text { Neutral n } \\
(\mathbf{\%})\end{array}$ & $\begin{array}{c}\text { Disagree n } \\
\mathbf{( \% )}\end{array}$ \\
\hline $\begin{array}{l}\text { Online teaching is better in learning than conventional } \\
\text { classroom learning }\end{array}$ & $0(0 \%)$ & $5(17 \%)$ & $25(83 \%)$ \\
$\begin{array}{l}\text { Online assessment is better than the conventional } \\
\text { assessment }\end{array}$ & $0(0 \%)$ & $4(13 \%)$ & $26(87 \%)$ \\
$\begin{array}{l}\text { In online classes, students are not actively involved in their } \\
\text { learning }\end{array}$ & $26(87 \%)$ & $1(3 \%)$ & $3(10 \%)$ \\
$\begin{array}{l}\text { I miss the face-to-face contact with students when teaching } \\
\text { online }\end{array}$ & $28(93 \%)$ & $1(3 \%)$ & $1(3 \%)$ \\
$\begin{array}{l}\text { In an online class, there is a lack of feedback from students } \\
\text { I have no problem controlling my students in the online }\end{array}$ & $\begin{array}{l}21(70 \%) \\
\text { environment. }\end{array}$ & $3(10 \%)$ & $6(20 \%)$ \\
$\begin{array}{l}\text { Quality of online teaching is affected by the computer/IT } \\
\text { skills of faculty members }\end{array}$ & $17(57 \%)$ & $6(27 \%)$ & $6(20 \%)$ \\
$\begin{array}{l}\text { Online class learning should be combined with classroom } \\
\text { learning in the future. }\end{array}$ & $18(60 \%)$ & $2(7 \%)$ & $7(23 \%)$ \\
\hline
\end{tabular}

$\mathrm{n}=$ Number of subjects

The majority of faculty members disagree with online teaching and assessment $(83 \%, 87 \%$, respectively) in comparison to conventional classroom teaching. The majority believe that the student was not actively involved in an online class, and they miss the face-to-face contact with students, and there was also a lack of feedback from the students. Regarding control of students during online teaching, as they could be muted and unmuted by the teacher, had varied opinion half agree while $1 / 4$ th neutral and other $1 / 4$ th disagree. Almost half of the faculty members stated that IT skills influenced online teaching and, at the same time, the majority of the staff's support combining offline and online classroom teaching. (Table 2)

Table 3. Comment Analysis of Medical Teachers about Online Teaching and Assessment

\begin{tabular}{clc}
\hline Index & Content of Investigation/User Experience & $\begin{array}{c}\text { Teaching } \\
\text { Faculty n (\%) }\end{array}$ \\
\hline & Covid-19 prevention & $9(30 \%)$ \\
& Ease of use & $9(30 \%)$ \\
Positive & New experience & $2(6.6 \%)$ \\
Comments & Resistance to e-teaching & $2(6.6 \%)$ \\
& Insufficient internet connectivity & $2(6.6 \%)$ \\
& No comments & $6(20 \%)$ \\
\hline Negative & Lack of interaction & $25(83.4 \%)$ \\
Comments & Insufficient internet connectivity & $5(16.6 \%)$ \\
\hline & Interactive with feedback & $14(46.6 \%)$ \\
& Improved network & $8(26.6 \%)$ \\
& Interactive with improved network & $1(3.3 \%)$ \\
Suggestions Training programs & $1(3.3 \%)$ \\
& Interactive with short groups and improved network with training programs & $1(3.3 \%)$ \\
& Online platform privacy & $1(3.3 \%)$ \\
No suggestion & $4(13.3 \%)$ \\
\hline
\end{tabular}

$\mathrm{n}=$ Number of Subjects 
According to online user comments analysis, $1 / 3$ of the staff believes that online teaching was need of the time to prevent COVID-19 infection. Almost $30 \%$ of faculty find it easy to use while others find it a novel experience; nonetheless, some faculty (6.6 percent) were resistant to switch-over to e-teaching. The negative aspect of e-teaching was lack of feedback from the student $(83 \%)$ and inadequate internet connectivity $(47 \%)$. The teaching faculty recommended interactive teaching in small groups with feedback, high-speed internet connectivity, and mandatory prior hands-on training to fix the technological difficulty. Only one faculty also take our attention to a safe and secure online platform. (Table 3)

\section{Discussion}

The effectiveness of every system is determined by the satisfaction of its users, in this context, teacher satisfaction with e-teaching is the prime requisite for the success of online learning. The present study found that the overall perception of the majority of teachers towards online teaching-learning quality was good, even though the majority of the teaching faculty $(67 \%)$ prefer face-to-face teaching. Inadequate network connectivity during delivering e-lectures was a big challenge that influences the quality of the e-learning as experienced by most of the faculty (60\%) members, along with technological issues (53\%). During the COVID-19 epidemic, the online platform met the faculty satisfaction towards teaching as well as assessment, with over half of the staff (43 percent and 47 percent, respectively) satisfied, whereas the remaining 30\% were dissatisfied. Teaching faculty attitude was more in favor of traditional classroom teaching as they miss the face-to-face contact and feedback from students. Similarly, a maximum of faculty $(87 \%)$ did not like online assessment since it does not cover all the domains of assessment. The majority of faculty believe that the online platform was the effective means for education during the COVID-19 pandemic, and it also provided a new experience. Faculty suggested that to promote the online teaching platform, e-classes should be in small groups, interactive with students' feedback and better internet connectivity, and prior hands-on training should be compulsory to resolve the technical problems.

In a faculty study about online teaching, Kapoor, et al., (2020) in Madhya Pradesh (India) discovered that while internet access was a barrier for 33 percent of faculty members and technology issues for 21 percent, just 4.3 percent felt a lack of human contact and eye contact. A study conducted by Al-Araibi, et al., (2019) revealed technical issues as the main criteria for the success of e-learning systems indicated that $45 \%$ of e-learning projects in developing countries were total failures, $40 \%$ were partial failures, while only $15 \%$ were successful. Research conducted at eight different Indonesian universities to investigate instructors' prospects also identified internet as a barrier up to some extent (Simamora, et al., 2020).

The study conducted at Alfaisal University Riyadh (Rajab, et al., 2020) prefers face-to-face teaching by $25 \%, 12 \%$ by online, and $62 \%$ by combined online with face-to-face interaction. They reported that the challenges during the COVID-19 pandemic were communication (59\%), student assessment $(57.5 \%)$, use of technology tools (56.5\%), experience in online education $(55.0 \%)$, and technophobia (17.0\%). In contrast to the present study (43\%), Elzainy, et al. (2020) at Qassim University found that staff satisfaction in virtual classrooms of the preclinical phase was very effective by $84 \%$ of faculty.

The present study found internet connectivity issues often faced by $27 \%$ and sometimes by $60 \%$ faculty, although the technological problems were faced less $(17 \%)$ by faculty as the college provides technical support. In contrast to Kapoor, et al. (2020) and Rajab, et al. (2020), the majority of present study staff $(67 \%)$ prefer face-to-face teaching, with $60 \%$ of faculty recommended that online learning should be integrated with traditional classroom learning in the future.

Previous research has identified the primary causes of e-learning failures. Many academics believe that the technological challenges that students confront when using an e-learning system are a key source of concern ( Al-Araibi, et al., 2019). The failure of an e-learning system can also be attributed to a lack of technological infrastructure within the university, which includes hardware, software, facilities, and network capabilities (Almaiah, \& Almulhem, 2018). Others 
focus on lack of technical support and technical employees, and a lack of facilities to carry out various operations (installation, operation, maintenance, network administration, and security), as well as poor internet speeds and high internet traffic throughout the e-learning experience (Eltahir, 2019). Faculty members' lack of information technology (IT) skills (Almaiah, \& Alyoussef, 2019) and adoption of e-learning technologies posed a significant difficulty in the transitional phase of smoothly conducting e-learning (Vershitskaya, et al., 2020). The lack of security and privacy was also a concern during e-learning since the openness of e-learning systems presents a challenge for the security of the personal information of students and faculty (Rajab, et al., 2020).

This COVID-19 outbreak was sudden during April 2020, teachers didn't have enough time to experiment with new technology, offline lectures switch to online education platforms. Furthermore, the concept of online education was in its infancy because the vast majority of teachers lacked sufficient knowledge of computer technology. Issues such as how to schedule classes, how to carry out online teaching according to plan, which online teaching platform to use, and how to monitor the effect and quality of online teaching may be the cause of decreased teacher satisfaction when faced with the abrupt introduction of online teaching.

While pandemics have historically posed difficulties, recognizing these difficulties is the first step toward turning them into possibilities. To meet the various challenges of e-learning, teachers must employ a range of strategies, including "you ask me a question," "Problem-based learning," "face to face video call," "students record e-lectures," and "real-time lecture" in small groups with interaction, rather than teaching by rote and lecturing. Students' learning interests and focus can be improved by increasing interaction.

\section{Implication and future research}

The present study proposes that the online education platform technology should be improved with better network infrastructure, which is expected to improve user satisfaction during public health education. Teachers should be trained in advance to deal with technophobic of the handling of computer hardware and software issues in the classroom. The administration must also handle the security and privacy of e-learning, as it poses a threat to the protection of students' and faculty's private information. The findings of this study can assist policymakers and developers at universities and colleges, as they present a realistic image of the current e-learning system and can be used as a guideline to increase the satisfaction of faculty towards the use of elearning systems for effective quality online learning. However, some aspects of this survey depended on participants' memory perhaps influencing their reporting, introducing elements of recall bias. Moreover, the study participants belonged to a single medical college; therefore, the findings are only applicable to similar contexts. For generalizability, a survey based on our findings should be conducted across the province or country including technical (medical education, engineering, etc) and non-technical (arts, etc) education systems. As learning is a continuous process, there is a need to explore alternative learning environment for efficient, effective, easy-to-access quality learning to cope up with the impact of an unpredictable future pandemic.

\section{CONCLUSION}

The COVID-19 pandemic transforms medical education into innovative e-learning. The teaching faculty adopt the online mode of education smoothly in the pandemic situation as nearly half of the faculty satisfies with e-teaching, but internet connectivity was a big challenge with some difficulty in technical handling of online classes. To accomplish faculty satisfaction and quality of e-lecture, the delivery of high-yielding quality of efficient teaching, platform technology should be upgraded with preceding hands-on training. The interaction, feedback, verbal and nonverbal communication with students were also the major aspects of teaching that were unable to replace in a virtual class. 


\section{ACKNOWLEDGEMENTS}

The authors would like to acknowledge the teachers for their valuable time and contributions.

\section{REFERENCES}

Al-Araibi, A. A. M., Mahrin, M. N, \& Yusoff, R. C. M. (2019). Technological aspect factors of Elearning readiness in higher education institutions: Delphi technique. Educ Inf Technol, 24, 567-590. https:// doi.org/10.1007/s10639-018-9780-9

Almaiah, M. A., \& Almulhem, A. (2018). A conceptual framework for determining the success factors of e-learning system implementation using Delphi technique. J of Theor Appl Inf Technol, 96(17), 1-15.

Almaiah, M. A., \& Alyoussef, I. Y. (2019). Analysis of the effect of course design, course content support, course assessment and instructor characteristics on the actual use of e-learning system. IEEE Access, 7, 171907-171922.

Alvin, M. D., George, E., Deng, F., Warhadpande, S., \& Lee, S. I. (2020). The impact of COVID-19 on radiology trainees. Radiology, 296, 246-8. https:// doi.org/10.1148/radiol.2020201222

Chiasson, K., Terras, K., \& Smart, K. (2015). Faculty perceptions of moving a face-to-face course to online instruction. J Coll Teach, 12,321. https:// doi.org/10.19030/tlc.v12i3.9315

Christiane Amanpour. (2020, April 1). How does the pandemic affect U.S. college students? Temple University, Philadelphia. Amanpour \& Co. https://www.pbs.org/wnet/amanpour-andcompany/video/how-does-the-pandemic-affect-u-s-college-students/

Dimock, M. (2019, January 17). Defining generations: Where millennials end and Generation Z begins. https://www.pewresearch.org/fact-tank/2019/01/17/where-millennials-end-andgeneration-z-begins/

Eltahir, M. E. (2019). E-learning in developing countries: Is it a panacea? A case study of Sudan. IEEE Access, 7, 97784-97792.

Elzainy, A., El Sadik A., \& Al Abdulmonem, W. (2020). Experience of e-learning and online assessment during the COVID-19 pandemic at the College of Medicine, Qassim University. Journal of Taibah University Medical Sciences, 15(6), 456-462. https://doi.org/10.1016/J.JTUMED.2020.09.005

Esani, M. (2010). Moving from face-to-face to online teaching. American Society for Clinical Laboratory Science, 23(3), 187-190. https:/ / doi.org/10.29074/ascls.23.3.187

Iyer, P., Aziz, K., \& Ojcius, D.M. (2020). Impact of COVID-19 on dental education in the United States. J Dent Educ, 84(6), 718-722. https:// doi.org/10.1002/jdd.12163

Kanneganti, A., Sia, C. H., Ashokka, B., \& Ooi, S. B. S. (2020). Continuing medical education during a pandemic: An academic institution's experience. Postgraduate Medical Journal, 2020,137840. https:// doi.org/10.1136/postgradmedj-2020-137840

Kapoor, A., Kapoor, A., Charokar, K., Mishra, A., Motagi, M. V., \& Sadawarte, S. K. (2020). A Faculty survey about online teaching during early lockdown period of COVID-19 pandemic in a medical college in central India. CHRISMED Journal of Health Research, 7(4), 265-270.

Mian, A., \& Khan, S. (2020). Medical education during pandemics: A UK perspective. BMC Medicine, 18(1), 100. https:// doi.org/10.1186/s12916-020-01577-y

Nicola, M., Alsafi, Z., Sohrabi, C., Kerwan, A., Al-Jabir, A., Iosifidis C., Agha, M., \& Agha, R. (2020). The socio-economic implications of the coronavirus pandemic (COVID19): A review. International Journal Surgery, 78, 185-193. https:// doi.org/10.1016/j.ijsu.2020.04.018

Panchabakesan, S. (2011). Problems and prospectives in distance education in India in the 21st century. Problems of Education in the 21st Century, 30, 113-122.

Rajab, M. H., Gazal, A. M., \& Alkattan, K. (2020). Challenges to online medical education during the COVID-19 pandemic. Cureus, 12(7). https://doi.org/10.7759/cureus.8966

Rose, S. (2020). Medical student education in the time of COVID-19. JAMA, 323(21), 2131-2132. https://doi.org/10.1001/jama.2020.5227 
Rosen L. D., \& Weil, M. M. (1995). Computer availability, computer experience and technophobia among public school teachers. Computers in Human Behavior, 11(1), 9-31. https://doi.org/10.1016/0747-5632(94)00018-D

Sandhu, P., \& Wolf, M. D. (2020). The impact of COVID-19 on the undergraduate medical $\begin{array}{llll}\text { curriculum. Medical Education } & \text { Online, }\end{array}$ https://doi.org/10.1080/10872981.2020.1764740

Simamora R. M., (2020). The challenges of online learning during the covid-19 pandemic: An essay analysis of performing arts education students. Studies in Learning and Teaching, 1(2), 86-103. https:// doi.org/10.46627/ silet.v1i2.38

Simamora R. M. , Fretes D. de, Purba E. D., Pasaribu D. (2020). Practices, challenges, and prospects of online learning during COVID-19 pandemic in higher education: Lecturer perspectives. Studies in Learning and Teaching, 1(3), 185-208. https:// doi.org/10.46627/silet.v1i3.45

Tabatabai, S. (2020). COVID-19 impact and virtual medical education. Journal of Advances in $\begin{array}{lllll}\text { Medical Education } \mathcal{E} & \text { Professionalism, } & \text { 8(3), }\end{array}$ https://doi.org/10.30476/jamp.2020.86070.1213

UNESCO. (2020). Education: From disruption to recovery. UNESCO. https://en.unesco.org/covid19/educationresponse

Vershitskaya, E.R., Mikhaylova, A. V., Gilmanshina, S. I., Dorozhkin, E. M., \& Epaneshnikov, V. V. (2020). Present-day management of universities in Russia: Prospects and challenges of elearning. Education and Information Technologies, 25, 611-621.

World Health Organization. (2019, December 31). Coronavirus disease (COVID-19)-events as they happen. https://www.who.int/emergencies/diseases/novel-coronavirus2019/events-as-they-happen

\footnotetext{
Author (s):

* Anuradha Yadav (Corresponding Author)

Department of Physiology,

SMS Medical College,

Jaipur, Rajasthan 302004, India

Email: dr.anuradhayadav@yahoo.co.in
}

Manisha Sankhla

Department of Physiology,

SMS Medical College,

Jaipur, Rajasthan 302004, India

Email: manisha_signsky@yahoo.com

Kavita Yadav

Department of Physiology,

SMS Medical College,

Jaipur, Rajasthan 302004, India

Email: kavita0616@gmail.com 